\title{
ORAÇÃO DE ENCERRAMENTO
}

\author{
M. ${ }^{a}$ da Graça Corte Imperial *
}

Ao término deste Congresso, em primeiro lugar quero apresentar, em nome de todos os congressistas, os agradecimentos à Enfermeira Jandira Orrico, Presidente da Associação Brasileira de Enfermagem/Seção da Bahia e aos colegas membros da Comissão Executiva pela brilhante organização. Todos sabem perfeitamente que este gênero de evento não é tarefa fácil de organizar, por este motivo, agradecemos aos colegas da Bahia de terem aceito com entusiasmo a empreitada, cujo sucesso foi a medida de suas dedicações. Agradecemos também a acolhida simpática e descontraída que nos prepararam nesta famosa cidade, com uma temperatura esplendida que aqueceu os sulistas da investida rigorosa do frio e para os nortistas e nordestinos moderou com as chuvas que caem, transformando-as em gotas de luar como na famosa canção em que a artista Clara Nunes tão bem decantou a Bahia.

O ambiente nos permitiu durante estes dias trabalhar, tanto nas Comissões, muito operosas, como intercambiar pontos de vista, apresentando experiências e realizações; ensejou alargar nossos horizontes, mostrando como se apresentam os mesmos problemas, para os quais se idealizaram soluções diversificadas. Esse confronto de idéias deve ser continuado. As coisas marcham com muita celeridade, na Enfermagem; por essa razão a publicação das experiências, dos pontos de vista deste Congresso devem ser estudados, divulgados pelas Seções para que no próximo Encontro tenhamos conhecimento dos resultados obtidos das recomendações.

Convido-os para, daqui a um ano nos reunirmos no Estado do Rio de Janeiro onde comemoraremos o cinqüentenário da nossa Associação para a realização do XXVIII Congresso Brasileiro de Enfermagem e o I Congresso Regional do CICIAMS.

Antes de encerrar, gostaria de fazer um pequeno balanço dos resultados positivos deste nosso Encontro: contamos com a presença das mais altas autoridades em questões de ensino, enfermagem, médicas e de organização; os trabalhos foram de ótima qualidade e serão publicados na Revista Brasileira de Enfermagem e devem constituir para todos os profissionais um repositório para consulta.

Nosso Governo também tomou conhecimento deste Congresso, especialmente através dos ministérios interessados, bem como, as autoridades deste Estado que com suas presenças e apoio irrestrito, provaram o interesse pela iniciativa.

Gestaria de agradecer em especial a todos que colaboraram na organização,

* Presidente. 
tanto na parte científica e social como na divulgação, sem suas ajudas nada teria sido possível.

Quero agradecer, especialmente à Dr. ${ }^{\mathrm{a}}$ Maria Ivete Ribeiro de Oliveira, que soube organizar e dinamizar a parte científica do Congresso.

Mais uma vez muito obrigada a todos, especialmente às delegações estaduais que em tão grande número vieram à Bahia. Espero rever a todos no Estado do Rio de Janeiro em 1976.

Muito obrigada.

Está encerrado o XXVII Congresso Brasileiro de Enfermagem. 